\title{
CSR activities in Sugar Mills during the Covid 19: A case study of Uttar Pradesh

\author{
Neeraj Singh*and Dr. Ashish Bajpai ${ }^{* *}$
} \\ *Assistant Professor- MABM Course, Department of Agricultural Economics, Institute of Agricultural Sciences, Banaras Contact- Email: neeraj168@gmail.com, Mobile: +91-8765625251 \\ **Professor, Institute of Management Studies, Banaras Hindu University- 221005, Varanasi.
}

\begin{abstract}
Corporate Social Responsibility (CSR in this paper) is a self-regulating business model that helps a company to be socially accountable - to itself, its stakeholders and the public. By practicing corporate social responsibility companies can be conscious of the kind of impact they are having on all aspects of society, including economic, social and environmental. CSR is not just another form of indirect expense but is important for protecting the goodwill and reputation, defending attacks and increasing business competitiveness.
\end{abstract}

This paper is an attempt to identify the variouS CSR activities performed by the selected sugar mills during the Covid 19 period and to and explain the opportunities and benefits of practicing CSR to the stakeholders involved. The paper is based on primary and secondary data collected through personal interviews, published articles, newspaper reports official websites etc.

Keywords: Stakeholders, Corporate Social Responsibility, satisfaction level

\section{Introduction}

Management as a subject states the first principle of a business that the prime objective of business organizations is to earn profits. Any expenditure which is not in line of primary objective will result in deduction in total profit. (Friedman, 1962, 1970) in his two studies stated CSR activities could harm the interests of other stakeholders through decreased return on investment for shareholders, increased prices of products for consumers, and lower wages for employees. Chepchirchir (2015) in a study concluded that organizations should develop a shared vision for their CSR programmes with its stakeholders this will enable them monitor its progress and be able to stand the test of time. There is also a greater need to engage both internal and external stakeholder to be able to prioritize their needs and learn from them some innovative strategies to be used to improve business.

The concept of CSR could be detrimental as well as contradictory to the main objectives of businesses, and may be considered mismanagement of corporate funds.Bernstein (2000) in his study states that business should be responsible to stakeholders even if it requires firms to sacrifice some profits. Firms should deal with these conflicting interests and claims in an ethical manner by formulating stakeholders' friendly policies. CSR advocates that businesses have responsibilities, which extend beyond making a profit, to society. Notwithstanding, a firm has social responsibilities, and is ethical responsible for its action because its strategic decisions often affect other stakeholders. This also supports the text prepared by Carroll and Buchholz (2003) which infers that CSR has inherit stakeholders expectations which are classified as economic, legal, ethical, and philanthropic expectations.Ahmadian and Khosrowpour (2017) identified two main drivers of CSR, public policy and business strategy, but there are as many drivers as there are firms in existence. Because firms operate in and amongst society it is only natural that they be aware of the public's demands and interests. This means that companies have greater expectations to try to to provide positive outcomes while mitigating the effects of negative outcomes which would affect the public. Business strategy as a driver of CSR takes into consideration costs and benefits. It can be assumed that implementing any new plan will come with costs, such as money, resources and personnel, but the unclear nature of CSR makes these costs even more risky.

However, a growing number of corporate executives believe that a strategic approach to CSR creates a competitive advantage for firms. CSR can be used to differentiate a company from its competitors by prompting consumer and employee goodwill (McWilliams, Siegel, \& Wright, 2006). CSR may also be used preemptively. By successfully implementing CSR practices a firm can force their competitors to engage in CSR as well. CSR positions companies to both proactively manage risks and take advantage of opportunities.

\section{Review of Literature}

The awareness and participation in CSR in India can be seen as both voluntary and by the external pressure from government and society (Mohan, 2001). The recent years have witnessed an increased awareness of CSR among business community in India resulting in more documentation 
of CSR initiatives (Shinde, 2005; Gautam and Singh, 2010). Tata Group was first to take initiatives and introduce CSR in their business policies (Gupta, 2007) and their contribution towards welfare programmes has resulted in maintaining cordial relations with labour unions and other stakeholders. In India, like other developing nations the factors affecting the decisions regarding CSR are internal as well as external. Baxi and Prasad (2009) identify the major drivers of CSR to be globalisation and competition, growing influence and size of corporations, retrenchment or repositioning of government and its roles, war for talent, competing for expertise, growth of global civil society activism, increased importance of intangible assets.

Baron (2001) in his study defined the term Strategic CSR which means use of CSR to attract socially responsible consumers in the sense that firms provide a public good in conjunction with their marketing/business strategy.

Clarkson (1995) defines and identifies various stakeholders present in an organization.

Jenson (2001) infers stakeholder theory as stating that managers should make decisions by accounting for the interests of all stakeholders in the organisation, and discusses whether or not organisations should maximize value.

In a study to explore the individuals' perception towards CSR and identifying its benefits to business and stakeholders in Kazakhstan, Yelena (2012) reported environmental friendliness, legal responsibility and stewardship principle to be important ones and the primary payback of CSR as to improve the image and reputation of companies.

Greening and Turban (2000), in a study concluded that people responsible for developing new markets, and building business and community relationships in the increasingly important emerging economies are seen as the new actors of the economic, social and environmental progress around the globe. It is argued that the leading companies of the future will be those that base their mission and their corporate strategies around creating, measuring and managing value.

Benefits to companies that have such structures within include: (1) enhanced corporate reputation among shareholders, customers, employees, communities etc. (2) reduced exposure to adverse publicity stemming from highprofile consumer or shareholder campaigns, and (3) reduced costs related to the inclusion of shareholder resolutions in annual proxy statements (Berman, Wicks and Kotha, 1999).

\section{Objectives of the study}

1. To figure out the CSR practices of selected sugar mills

2. To identify the concern towards beneficiaries of the sugar mills while practising CSR activities during COVID-19

\section{Research Methodology}

This research paper is an example of exploratory cum descriptive research which is supported by primary data collected via personal interview of senior officials of the selected sugar mills and the secondary data sourced from journals, magazines, articles and media reports. Farmers were identified as the stakeholders and 50 farmers were randomly selected for the responses. Looking into the objectives of the study the research design employed for the study is descriptive research design. This research design was adopted to possess greater accuracy and thorough analysis of the research study. Secondary data have comprehensively used for the study. Information from different news articles, Books and Web sources are used which are recorded and enumerated.

\section{Results and Discussion}

\section{Conclusion for Objective 1}

Corporate Social Responsibility (CSR) is basically what an organization does to positively influence the society in which it exists. It could take the form of community relations,

\begin{tabular}{|c|c|c|}
\hline Type of Stakeholders & Identified Stakeholders & Features \\
\hline Primary stakeholders groups & $\begin{array}{l}\text { Shareholders } \\
\text { Employees, } \\
\text { Customers, and } \\
\text { Suppliers }\end{array}$ & $\begin{array}{l}\text { Without primary stakeholders continuous participa- } \\
\text { tion the corporation cannot survive. }\end{array}$ \\
\hline Secondary stakeholder groups & $\begin{array}{l}\text { Competition, } \\
\text { Media, } \\
\text { Trade associations, and } \\
\text { Support groups (special interest). }\end{array}$ & $\begin{array}{l}\text { These groups have no contract or authority with the } \\
\text { firm. } \\
\text { The firm is not dependent upon these groups for } \\
\text { their survival. } \\
\text { These groups still can cause significant disruption to } \\
\text { the firm }\end{array}$ \\
\hline
\end{tabular}


volunteer assistance programs, healthcare initiatives, special education / training programs and scholarships, preservation of cultural heritage and beautification of cities/towns

A list of sugar mills functioning in India according to net profit (eligible for mandatory to spend a minimum amountAs per company's act 2013) was obtained from Moneycontrol. com. Further the companies were identified which were functioning in UP. According to the official websites and annual reports of such sugar mills the CSR practices were studied and the following results were obtained:

Further the specific activities of CSR were identified of each sugar mill with the help of information available on the official website.

\section{Conclusion for Objective 2}

\begin{tabular}{|c|c|c|c|}
\hline Name of Sugar Mill & Profit (in cr.) & State of Head Office & Broad area of CSR activities \\
\hline Balrampur Chini & 509.28 & UP & Education, Health, Sports, \\
\hline Bajaj Hindusthan Sugar Mill & NA & UP & Education, Health, Environment, \\
\hline $\begin{array}{l}\text { Source: Moneycontrol- } \\
\text { Weblinkhttps://www.money- } \\
\text { control.com/stocks/marketinfo/ } \\
\text { netprofit/bse/sugar.html?clas- } \\
\text { sic=true }\end{array}$ & & & \\
\hline
\end{tabular}

To fulfil the second objective of the study it was important to explore various benefits of practising CSR and have a brief idea about the various responsibility categories.

(Prasad, 2015) states the following benefits of CSR for any corporation:

- Improved financial performance;

- Lower operating costs;

- $\quad$ Enhanced brand image and reputation;

- Increased sales and customer loyalty;

- Greater productivity and quality;

- More ability to attract and retain employees;

- $\quad$ Reduced regulatory oversight;

- $\quad$ Access to capital;

\begin{tabular}{|l|l|l|l|}
\hline Name of Sugar Mill & Official website & Broad area of CSR activities & Specific activities performed as per official website \\
\hline Balrampur Chini & https://chini.com/ & $\begin{array}{l}\text { Four Mobile Science Labs to Agastya International Foundation } \\
\text { (AIF) for providing hands-on training to school students in various } \\
\text { science subjects through school and community visits in the areas of } \\
\text { LakhimpurKheri, Gonda, Balrampur and Barabanki (all in the State of } \\
\text { Uttar Pradesh). } \\
\text { Education, Health, Sports, } \\
\text { The Company is engaged in the promotion of wrestling in collaboration } \\
\text { with the Uttar Pradesh Wrestling Association. National-level wrestling } \\
\text { tournaments have been organised in Gonda district by Uttar Pradesh } \\
\text { Wrestling Association. }\end{array}$ \\
$\begin{array}{l}\text { Balrampur Institute of Vocational Aid (BIVA) was promoted by } \\
\text { Balrampur Chini in Kolkata to provide vocational training to the } \\
\text { unemployed; more than 640 people are taught in 15 courses (three } \\
\text { government-affiliated) at subsidised rates each year. }\end{array}$ \\
\hline
\end{tabular}




\begin{tabular}{|c|c|c|c|}
\hline Name of Sugar Mill & Official website & $\begin{array}{l}\text { Broad area of CSR } \\
\text { activities }\end{array}$ & $\begin{array}{l}\text { Specific activities performed as per official } \\
\text { website }\end{array}$ \\
\hline $\begin{array}{l}\text { Bajaj Hindusthan Sugar } \\
\text { Mill }\end{array}$ & $\begin{array}{l}\text { http://www.bajajhindusthan.com } \\
\underline{\text { https://www.bajajgroup.org/sustainability }}\end{array}$ & $\begin{array}{l}\text { Education, Health, } \\
\text { Environment, }\end{array}$ & $\begin{array}{l}\text { Natural Resource Management: } \\
\text { Revive the dilapidated river systems of the farm- } \\
\text { ing villages in order to sustainably uplift the rural } \\
\text { economy. } \\
\text { Enhancement of Livelihood Opportunity: } \\
\text { Introduce farmers to sustainable agricultural } \\
\text { practices and relevant technologies which are } \\
\text { economically viable too. } \\
\text { Transforming Lives: } \\
\text { Initiate multiple developmental interventions in } \\
\text { the field of agriculture to empower the farming } \\
\text { community. } \\
\text { Partnering for Growth: } \\
\text { Extend a collaborative approach towards the ag- } \\
\text { riculture community and other developmental } \\
\text { stakeholders to enable the growth of the farm- } \\
\text { ers. }\end{array}$ \\
\hline
\end{tabular}

- Workforce diversity;

- $\quad$ Product safety and decreased liability.

(Weber 2008) identified the following five as the benefits of CSR.

- Positive effects on company image and reputation

- Positive effects on employee motivation, retention, and recruitment

- Cost savings

- Revenue increases from higher sales and market share

- CSR-related risk reduction or management

\section{Disadvantages and Issues of CSR}

Sivaranjini, Rekha and Nisha in their study identified following disadvantages of CSR:

Work environments can be frustrating- From antiquated technology to bureaucratic red tape, working at a non-profit can be downright exasperating. Employees are asked to try to do more work with fewer resources, create miracles on a day to day basis, and satisfy competing interests. The pace of change is usually slower as compared a for-profit environment, as long as numerous opinions must be considered and therefore the bottom line isn't as clear.
The level of burnout is high- those that enter the non-profit workforce with a selected mission and goal in mind do so with great purpose. This great purpose often places an important weight on the shoulders of these doing the work.

The stakes are higher- A bad day in a corporate job is unlikely to resemble a bad day in a non-profit job. Consider the difference between losing a couple of percent off your stock price and losing a mentored youth to drugs. The stakes are simply higher once you are handling a cause on the brink of your heart.

There is a continuing specialise in fundraising- Non-profit executives awaken every morning and attend bed nightly worrying about the situation of their next fundraised dollar. This constant pressure results in certain internal issues going unaddressed until a crisis emerges, takes the chief executive far away from the office for long periods of your time, and can lend it to mission drift.

\section{Conclusion}

The emerging concept of CSR advocates moving away from a 'shareholder alone' focus to a 'multi-stakeholder' focus. This would include investors, employees, business partners, customers, regulators, supply chain, local communities, the environment and society at large. In this paper it was identified that the targeted stakeholder's were given due importance 
while framing the CSR policies and the required course of action. The stakeholders were satisfied with the mills as they have got the desired items. The sugar mills are working at their level best in the COVID-19 time and depending upon the profits earned they were deciding the activities for the CSR. Organization 1 was focussing on the fact that the farmers should be generating income in COVID-19 and their profit amount permitted for distribution of agricultural inputs. Organization 2 was focussing on the fact that staying safe should be the utmost preference and their profits allowed the distribution of masks, sanitizers, food grains etc.

\begin{tabular}{|l|l|l|l|}
\hline \multicolumn{1}{|c|}{ Activity } & $\begin{array}{c}\text { Responses of identified stake- } \\
\text { holder (Farmers) }\end{array}$ & \multicolumn{1}{|c|}{ Type of contribution } \\
\cline { 2 - 4 } & $\begin{array}{l}\text { Distribution of Agricultural } \\
\text { inputs like power sprayers, } \\
\text { tippler trolleys, MB Plough } \\
\text { etc }\end{array}$ & $\begin{array}{l}90 \% \text { of the farmers who were as- } \\
\text { sociated with the mill informed } \\
\text { that the officials of the sugar mills } \\
\text { used to enquire about problems in } \\
\text { farming and then in the upcoming } \\
\text { season the mill used to arrange the } \\
\text { product }\end{array}$ & $\begin{array}{l}\text { Direct Benefit Transfer or DBT in the } \\
\text { form of cash or subsidies ranging } \\
\text { from } 50 \% \text { to } 100 \% \text { was transferred in } \\
\text { the account of the farmers. }\end{array}$ \\
\cline { 2 - 5 } & Distribution of tractors, small \\
tractors etc & $\begin{array}{l}\text { In this case 100\% of the farmers re- } \\
\text { sponded that they have asked for } \\
\text { help from the sugar mill officials } \\
\text { and got the demanded item. }\end{array}$ & $\begin{array}{l}50 \% \text { subsidy was transferred in the } \\
\text { account of the beneficiaries. The mill } \\
\text { arranged a meeting with the farmers } \\
\text { and reprentatives of a identified } \\
\text { to make thufacturing organization } \\
\text { and transparent. }\end{array}$ \\
\hline
\end{tabular}

\begin{tabular}{|l|l|l|l|}
\hline \multirow{2}{*}{ Organization 2 } & \multicolumn{1}{|c|}{$\begin{array}{c}\text { Responses of identified stakehold- } \\
\text { er (Farmers) }\end{array}$} & \multicolumn{1}{|c|}{ Type of contribution } \\
\cline { 2 - 4 } & $\begin{array}{l}\text { Distribution of masks, sani- } \\
\text { tizers, food grains to the as- } \\
\text { sociated farmers during the } \\
\text { lockdown period. }\end{array}$ & $\begin{array}{l}\text { In this case 100\% of the farmers re- } \\
\text { sponded that they have asked for } \\
\text { help from the sugar mill officials and } \\
\text { got the demanded item. }\end{array}$ & $\begin{array}{l}\text { Farmers were provided cloth for } \\
\text { mask stitching and once they had } \\
\text { stitched the masks the masks were } \\
\text { distributed among the farmers. San- } \\
\text { itizers were given to the families of } \\
\text { farmers and food grains required for } \\
1 \text { month was distributed }\end{array}$ \\
\cline { 2 - 4 } & $\begin{array}{l}\text { Installation of RO machines, } \\
\text { sanitization of nearby hospi- } \\
\text { tals and organization of train- } \\
\text { ing programs }\end{array}$ & $\begin{array}{l}\text { The mill with the help of CSR team } \\
\text { identified the suitable places for } \\
\text { representatives of SHG's and farmers } \\
\text { approached to the mill seeking some } \\
\text { help. }\end{array}$ & $\begin{array}{l}\text { RO installation and took necessary } \\
\text { steps. The mill also sanitised the } \\
\text { nearby hospital buildings and ar- } \\
\text { ranged some training programs for } \\
\text { the farmers regarding awareness of } \\
\text { COVID-19. }\end{array}$ \\
\hline
\end{tabular}

\section{References}

1. Ahmadian, A and Khosrowpour, S(2017) "Corporate Social Responsibility:Past, Present, And Success StrategyFor The Future" Journal of Service Science, Volume \& Issue 10(1), pp 1-12, ISSN: 19414722 (print)/ ISSN: 1941-4730 (online)

2. Baron, D. (2001). "Private Politics, Corporate Social Responsibility, and Integrated Strategy". Journal of Economics \& Management Strategy. Volume \& Issue: 10(1), pp 7-45, ISSN: 1530-9134

3. Berman, S.L., Wicks, A. C., Kotha, S., Jones, T. M. (1999). Does stakeholder Orientation matter? The relationship between stakeholder Management models and firm financial performance. Academy of Management, Volume \& Issue 42 (5): pp488-506.ISSN (print): 0001-4273 | ISSN (online): 1948-0989
4. Bernstein, A. (2000). Too much corporate power. BusinessWeek, 11 September, 149.

5. Carroll, A. B, \&Buchholtz, A. K. (2003). Business and society: ethics and stakeholder management. 5th ed. Mason (Ohio): South-Western Thomson learning. ISBN:0324114958

6. Chepchirchir, S C(2015), "Corporate Social Responsibility and Society "Challenges and Way Forward”The International Journal Of Business \& Management, Volume \& Issue 3(8), pp 119-121, ISSN: 2321 -8916

7. Clarkson, M. (1995). 'A stakeholder framework for analyzing and evaluating corporate social performance', Academy of Management Review, Vol 20(1), pp (92-117), ISSN (print): 0363-7425 | ISSN (online): 1930-3807 e-ISSN : 2278-487X, p-ISSN : 2319-7668

8. Friedman M. (1962). Capitalism and Freedom. Chicago University Press: Chicago, IL, USA. 
9. Friedman M. (1970). The social responsibility of business is to increase its profits. New York Times Magazine pp 32-33, Article viewed online on July 17,2020 from the following link : https://www.nytimes. com/1970/09/13/archives/a-friedman-doctrine-the-social-responsibilityof-business-is-to.html

10. Greening, D. W., \& Turban, D. B. (2000) 'Corporate social performance as a competitive advantage in attracting a quality workforce'. Business \& Society, Volume \& Issue39 (3): pp 254-280. ISSN: 0007-6503/Online ISSN: 1552-4205

11. Jenson, M.C. (2001). 'Value maximization, stakeholder theory, and the corporate objective function', European Financial Management, Vol. 7(3): pp (297-317). ISSN (Online):1468-036X

12. McWilliams, A., Siegel, D. S., \& Wright, P. M. (2006). Corporate social responsibility: Strategic implications. Journal of Management Studies, Volume \& Issue 43(1), pp1-18. Online ISSN:1467-6486

13. Prasad, KVS. (2015) "Corporate Social Responsibility: Practices and Challenges in Indian Prospective"; SUMEDHA Journal of Management, Vol \& Issue 4(3) pp (137-151) Print ISSN: 2277-6753. Online ISSN: 2322-0449.

14. Sivaranjini, P, Rekha, T, Nisha, T.S.,(YEAR of Publication is not available) Issues and Challenges Faced By Corporate Social Responsibility In Community Development, India Human Resource Development, IOSR Journal of Business and Management (IOSR-JBM), PP 58-61
15. Weber, $\mathrm{M}$ (2008), "The business case for corporate social responsibility: A company-level measurement approach for CSR". European Management Journal, Vol 26: pp247-261.ISSN: 0263-2373

16. Yelena, S. (2012) 'Perceptions of corporate social responsibility in Kazakhstan', Social Responsibility Journal, Vol. 8, No. 3, pp.404417ISSN:1747-1117

17. Baxi, C.V. and Prasad, A. (2009) Corporate Social Responsibility: The Indian Experience, Excel Books, New Delhi.

18. Gautam, R. and Singh, A. (2010) 'Corporate social responsibility practices in India: a study of top 500 companies', Global Business and Management Research: An International Journal, Vol. 2, No. 1, pp.41-56.

19. Gupta, D. (2007) 'Corporate Responsibility', in Corporate Social Responsibility: Concepts and Cases, The Indian Experience, Excel Publication, New Delhi.

20. Mohan, A. (2001) 'Corporate citizenship: perspectives from India', Journal of Corporate Citizenship, No. 2, pp.107-117.

21. Shinde, S. (2005) Social Responsibility Corporate Style [online] http:// www.expresscomputeronline.com/20050502/technologylike01.shtml. 